\title{
RADIOCARBON IN DISSOLVED ORGANIC AND INORGANIC CARBON FROM THE CENTRAL NORTH PACIFIC
}

\author{
ELLEN R M DRUFFEL*, PETER M WILLIAMS** \\ KEN ROBERTSON**, SHEILA GRIFFIN*, A J T JULL ${ }^{\dagger}$ \\ DOUGLAS DONAHUE ${ }^{\dagger}$, LAWRENCE TOOLIN $^{\dagger}$ and T $\mathrm{W}^{\prime}$ LINICK $^{\dagger}$
}

\begin{abstract}
Radiocarbon measurements are reported for dissolved organic carbon (DOC) and inorganic carbon (DIC) from seawater samples collected from the Alcyone-5 cruise in the central North Pacific Ocean in 1985. Differences between the UV-radiation techniques used here and those reported by Williams, Oeschger and Kinney (1969) to oxidize and recover the DOC from sea water are presented. UV unoxidizable DOC in these samples is discussed in a separate publication (Druffel, Williams \& Suzuki, 1989). We briefly discuss the penetration of the bomb ${ }^{14} \mathrm{C}$ signal into the DOC and DIC pools. The temporal variability of $\Delta^{14} \mathrm{C}$ in DIC in surface samples taken every $2-3$ days is presented. Concentrations of total dissolved free (FAA) plus combined (hydrolyzable) amino acids (THAA) and total dissolved carbohydrates (TCHO) measured in the same water samples are also reported. Our main aim is to present the chemical and isotopic data from samples collected during the Alcyone-5 cruise. Detailed interpretation is published elsewhere.
\end{abstract}

\section{INTRODUCTION}

The origin of DOC in ocean water has long been the subject of debate. We have some basic knowledge of the sources and sinks of the carbon to the DOC pool. Inputs of DOC to sea water include intra- and extra-cellular solubles produced by phytoplankton and from sloppy feeding by zooplankton, dissolution of fecal material, plus DOC derived from atmospheric and riverine inputs. Less is known about the source of DOC from subsurface vents, sediments and living bacteria. Sinks for DOC include microbial utilization, coalescence to form particles and adsorption onto existing particles. Quantitative assessments of the importance of each of these processes are not fully evaluated. Overall, it appears that DOC is derived primarily from marine sources, considering the similarity of the $\delta^{13} \mathrm{C}$ in DOC and in marine organisms (Williams \& Gordon, 1970) and the low concentration of lignin present in sea water (Meyers-Schulte \& Hedges, 1986).

${ }^{14} \mathrm{C}$ was measured nearly two decades ago in DOC from the northeast Pacific to determine its turnover time in the ocean. Williams, Oeschger and Kinney (1969) reported $\Delta^{14} \mathrm{C}$ values of $-351 \pm 27 \%$ at $1880 \mathrm{~m}$ and $-341 \pm 23 \%$ at $1920 \mathrm{~m}$ collected in 1968 and 1969 , respectively, from $30^{\circ} \mathrm{N}, 120^{\circ} \mathrm{W}$. Two years later, four samples from $30^{\circ} \mathrm{N}, 140^{\circ} \mathrm{W}$ were measured $(-88 \pm 20$, $-11 \pm 18,-176 \pm 14,-274 \pm 13 \%$ from $10 \mathrm{~m}, 200 \mathrm{~m}, 500 \mathrm{~m}$ and $2000 \mathrm{~m}$, respectively) (Arhelger et al, 1974; Williams et al, 1978). These ${ }^{14} \mathrm{C}$ analyses were performed on $\mathrm{CO}_{2}$ resulting from UV-oxidation of acidified sea water. L Jeffries (unpub data) used adsorption onto activated charcoal as a means for separating the DOC from sea water. Her measurements on Gulf of Mexico water were $-485 \%$ at $690 \mathrm{~m}$, and $-560 \%$ at $2290 \mathrm{~m}$ (Bada \& Lee, 1977). Gas proportional counting techniques were used to measure ${ }^{14} \mathrm{C}$ in these samples, thus, $500-1000 \mathrm{~L}$ of sea water were needed to make an analysis. Based on these early studies, deep-sea DOC has been assigned an apparent age of $3400 \mathrm{yr}$ BP.

\footnotetext{
*Woods Hole Oceanographic Institution, Woods Hole, Massachusetts 02543

** Scripps Institution of Oceanography, University of California, San Diego, La Jolla, California 92093

${ }^{\dagger}$ Department of Physics, University of Arizona, Tucson, Arizona 85721
} 
A recent study by Williams and Druffel (1987) reveals that the $\Delta^{14} \mathrm{C}$ of UV-oxidizable DOC in the deep Pacific is much lower than previously reported. We present these measurements and concentrations of FAA, THAA and TCHO in dissolved organic matter from a detailed profile in the central North Pacific. From a near high-precision $\Delta^{14} \mathrm{C}$ profile measured in DIC $\left(\Delta^{14} C_{\text {DIC }}\right)$, we examine the penetration of the bomb ${ }^{14} \mathrm{C}$ transient into the main thermocline since the GEOSECS survey of 1973. In addition, $\Delta^{14} C_{\text {DIC }}$ was measured in surface water samples collected every 2-3 days during the Alcyone-5 cruise to study short-term variability at a single open ocean site. The effect of a high wind storm on this short-term variability was also observed.

\section{Collection of Samples}

METHODS

The data presented here are from samples collected aboard the $R / V$ Melville during the Alcyone-5 cruise to the central North Pacific Ocean in October and early November 1985 . One location was occupied $\left(20 \mathrm{~km}^{2}\right.$, $\left.31^{\circ} \mathrm{N}, 159^{\circ} \mathrm{W}\right) 800 \mathrm{~km}$ north of Oahu, Hawaii in the predominantly eastward flowing North Pacific Current.

Gerard barrels, constructed of stainless steel with a volume of $270 \mathrm{~L}$, were used to obtain sufficient carbon for near high-precision $\Delta{ }^{14} \mathrm{C}$ analyses of the DIC fraction. The barrels were scrubbed and rinsed clean with dilute $\mathrm{HCl}$, xylene, acetone, methanol and distilled water to remove all traces of oil and other organic matter, as well as inorganic carbon. Partial disassemblage of the barrels was required so that o-ring grooves could be cleaned and viton o-rings installed. The plastic parts on the barrels were replaced with similar items constructed of brass (ie, water spigot). Barrels were mounted on the trawl wire and lowered to the desired depths. For near surface samples, a minimum of 20 min elapsed before the messenger was sent to close the lids to allow for adequate flushing at the desired depth. Drains and other tanks aboard ship were flushed out away from the immediate collection site. For the deeper samples, reversing thermometers were used to provide depth corrections, and salinity and silicate measurements from piggy-backed 5L Niskin bottles were compared with those from the barrels to check for pre-tripping or partial closure of the barrels.

Water for DOC concentration and ${ }^{14} \mathrm{C}$ analysis was filtered using a prefired $\left(500^{\circ} \mathrm{C}\right) \mathrm{GFC}$ glass fiber filter in a PVC holder that attached directly onto the spigot at the bottom of the Gerard barrel. One-gal glass bottles, which were previously cleaned with hot chromic acid, rinsed with double distilled water and protected from the atmosphere, were then rinsed three times with the sample water and filled. They were then sealed with teflonlined caps and frozen at $-20^{\circ} \mathrm{C}$. Four bottles were collected from depths below $450 \mathrm{~m}$ and two bottles were taken from shallower depths.

Aliquots of the same filtered sea water were collected in cleaned bottles for FAA, THAA and TCHO analyses, and frozen at $-20^{\circ} \mathrm{C}$. One- $\mathrm{L}$ samples from the upper $150 \mathrm{~m}$ were collected and immediately filtered for chlorophyl-a and phaeophyton analyses. Samples were taken for total $\mathrm{CO}_{2}$ ([DIC]) and alkalinity $(250 \mathrm{ml})$. 
The remainder of the water was pumped (using a Jabsco pump), unfiltered, into a plastic $220 \mathrm{~L}$ plastic drum. The water was acidified, heated $\left(50^{\circ} \mathrm{C}\right)$ and purged of $\mathrm{CO}_{2}$ using a peristaltic pump. The purged $\mathrm{CO}_{2}$ was absorbed into a solution of $\mathrm{SrCl}_{2}$ and concentrated ammonium hydroxide, wherein strontium carbonate was precipitated (Linick, 1975).

\section{Radiochemical and Chemical Analyses}

For the dissolved organic ${ }^{14} \mathrm{C}\left(\mathrm{DO}^{14} \mathrm{C}\right)$ analyses, 1gal samples were quickly defrosted in warm water and $5 \mathrm{~L}$ introduced into an all-glass reactor (Fig 1), acidified to $\mathrm{pH} 2.5 \pm 0.2$ with $50 \% \mathrm{H}_{3} \mathrm{PO}_{4}$, and sparged-free of DIC with nitrogen gas (organic and inorganic carbon-free) at $425 \mathrm{ml} \mathrm{min}-1$ for 3 $\mathrm{hr}$. The sea water was then saturated with clean oxygen gas and the reactor vessel closed using $85 \% \mathrm{H}_{3} \mathrm{PO}_{4}$ to lubricate and seal the glass ball joints. The sample was oxidized for $6 \mathrm{hr}$ using a 1200 watt Hanovia $\mathrm{Hg}$-arc lamp at $70-75^{\circ} \mathrm{C}$. The resultant $\mathrm{CO}_{2}$ derived from DOC was passed through the KI trap to collect chlorine gas, and water frozen out in the first Horibe trap cooled with dry-ice isopropanol. The sample was then collected in the second Horibe trap (Fig 1) using liquid $\mathrm{N}_{2}$. This collection was done by sparging the reactor with nitrogen gas at $235 \mathrm{ml} \mathrm{min}-1$ for $2 \mathrm{hr}$ at atmospheric pressure. The trapped $\mathrm{CO}_{2}$ was then pumped free of condensed air using the rough vacuum, and transferred successively from the Horibe trap to the Utube, then to the cold finger below the Pirani gauge. After measuring the $\mathrm{CO}_{2}$ pressure, the $\mathrm{CO}_{2}$ was split into samples for ${ }^{13} \mathrm{C}$ and ${ }^{14} \mathrm{C}$ analyses.

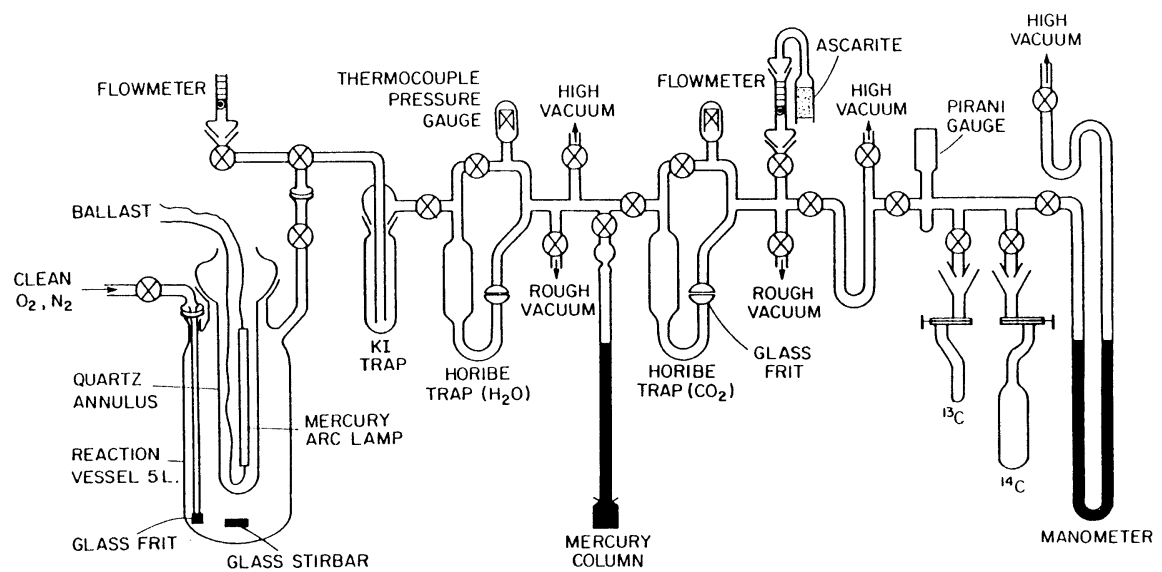

Fig 1. Schematic diagram of the vacuum line used for oxidation and extraction of DOC from sea water. See text for detail. 
The $\mathrm{CO}_{2}$ from the DOC was converted to graphite at the University of Arizona (Jull et al, 1986). ${ }^{14} \mathrm{C}$ was measured using AMS techniques at the University of Arizona TAMS Facility (Linick et al, 1986). Errors of \pm 4 $15 \%$ were obtained, and were dependent upon sample size and AMS system stability at the time of analysis. $\Delta^{14} \mathrm{C}$ was calculated assuming a $\delta^{13} \mathrm{C}$ of $-21 \%$ for the graphite targets. $\delta^{13} \mathrm{C}$-DOC measurements reported in Table 1 were performed on $\mathrm{CO}_{2}$ obtained directly from the UV oxidation of DOC in sea water.

For the $\mathrm{DI}^{14} \mathrm{C}$ analyses, the strontium chloride and ammonium hydroxide solution was decanted off, then heated to dryness, leaving solid strontium carbonate. $\mathrm{CO}_{2}$ was liberated using $4 \mathrm{~N} \mathrm{HCl}$, and converted to acetylene gas (Griffin \& Druffel, 1985). The acetylene samples were counted for 4-6 2-day periods in quartz gas proportional beta counters at $90.0 \mathrm{~cm} \mathrm{Hg}$ and $21^{\circ} \mathrm{C}$. Errors ranged from $\pm 2.4-3.6 \%$ as determined from counting statistics. $\delta^{13} \mathrm{C}_{\text {DIC }}$ was measured on $\mathrm{CO}_{2}$ from reburned acetylene gas samples.

The FAA and THAA analyses were done using HPLC fluorimetric determination of the o-pthaldialdehyde derivatives (Lindroth \& Mopper, 1979), after acid hydrolysis of the combined amino acids (Robertson, Williams \& Bada, 1987). The TCHO was measured spectrophotometrically on hydrolyzed samples using a modification of the procedure of Burney and Sieburth (1977) and are reported as glucose equivalents. The conversion factor for amino acids (nM) to carbon is 4.4 times amino acid concentration, and for the carbohydrates $(\mu \mathrm{M})$, this factor is 6 times the glucose equivalents.

\section{RESULTS AND INTERPRETATION}

The $\Delta{ }^{14} \mathrm{C}_{\mathrm{DOC}}$ and $\Delta{ }^{14} \mathrm{C}_{\mathrm{DIC}}$ data and results of chemical analyses are listed in Table 1. Figure 2 shows the $\Delta^{14} C_{D O C}$ and $\Delta^{14} C_{D I C}$ results. An initial discussion and a graphic representation of all but two of the $\Delta^{14} C_{D O C}$ results were presented by Williams and Druffel (1987).

The $\Delta^{14} C_{\text {DOC }}$ values in the upper $2000 \mathrm{~m}$ of the water column are 60 $220 \%$ lower than those from the same depths observed in the earlier studies (Williams, Oeschger \& Kinney, 1969; Arhelger et al, 1974, Williams et al, 1978). Though the earlier results were obtained from $1300-2600 \mathrm{~km}$ east, the differences in $\Delta^{14} C_{\mathrm{DOC}}$ are probably not due to location. We believe that the earlier results are due to incomplete oxidation of the lower activity (older) fraction of DOC as the original yields were only of the order of $70 \%$ of the total UV-oxidizable fraction.

The $\Delta^{14} C_{D I C}$ results are plotted $v s$ those reported by Östlund and Stuiver $(1980)$ for the GEOSECS Station $212\left(30^{\circ} \mathrm{N}, 160^{\circ} \mathrm{W}\right)$ in September 1973 (Fig 2b). These data show that bomb ${ }^{14} \mathrm{C}$ has penetrated an additional $150 \mathrm{~m}$ in $12 \mathrm{yr}$, from ca $850-1000 \mathrm{~m}$. The prebomb $\Delta{ }^{14} \mathrm{C}_{\text {DIC }}$ profile in the upper ocean is shown for comparison.

$\Delta^{14} C_{D O C}$ values are $300 \%$ ower than the $\Delta^{14} C_{\text {DIC }}$ values at all depths of the water column (Fig 2c). The similarity in the shape of the two profiles 


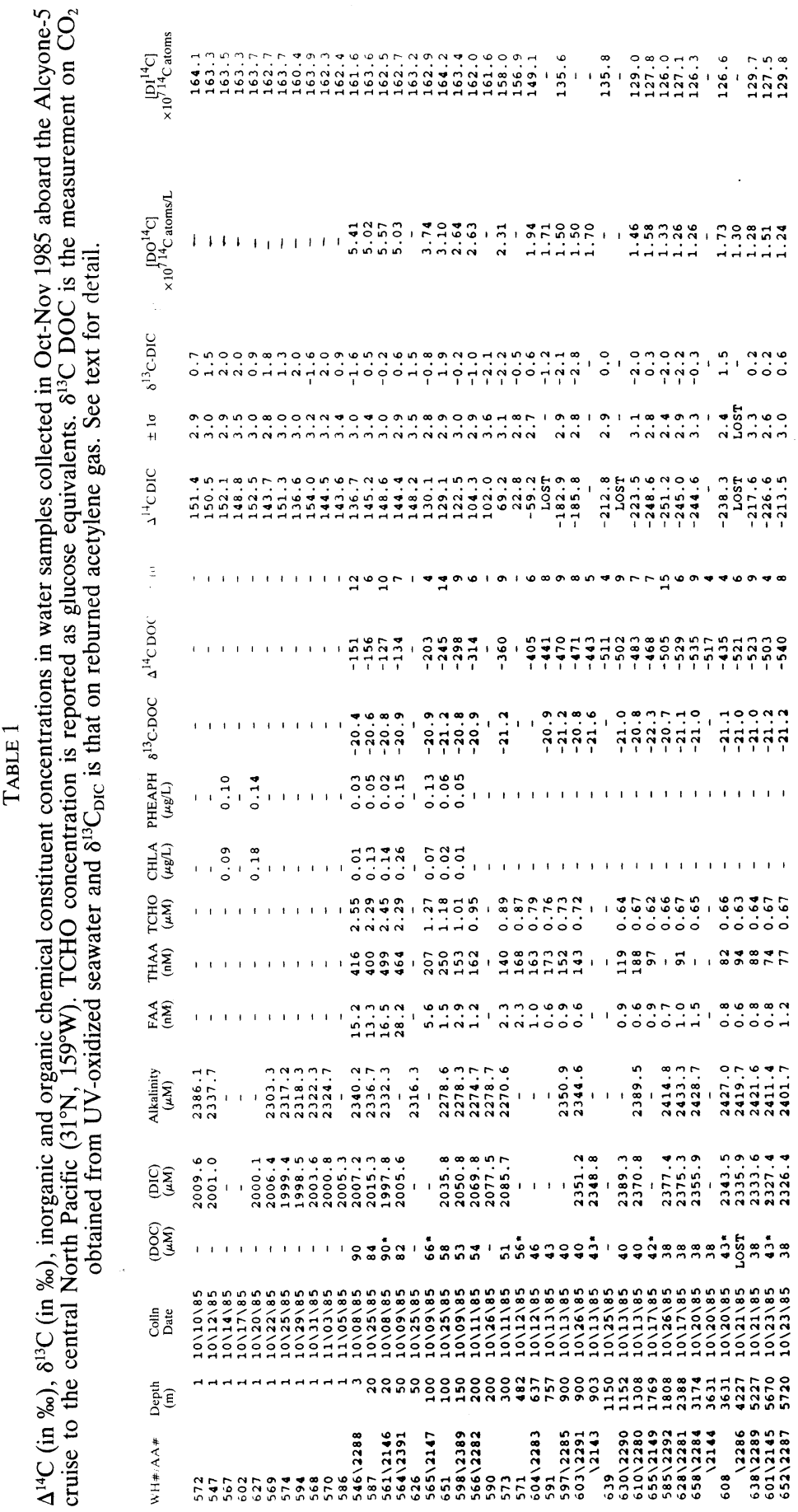



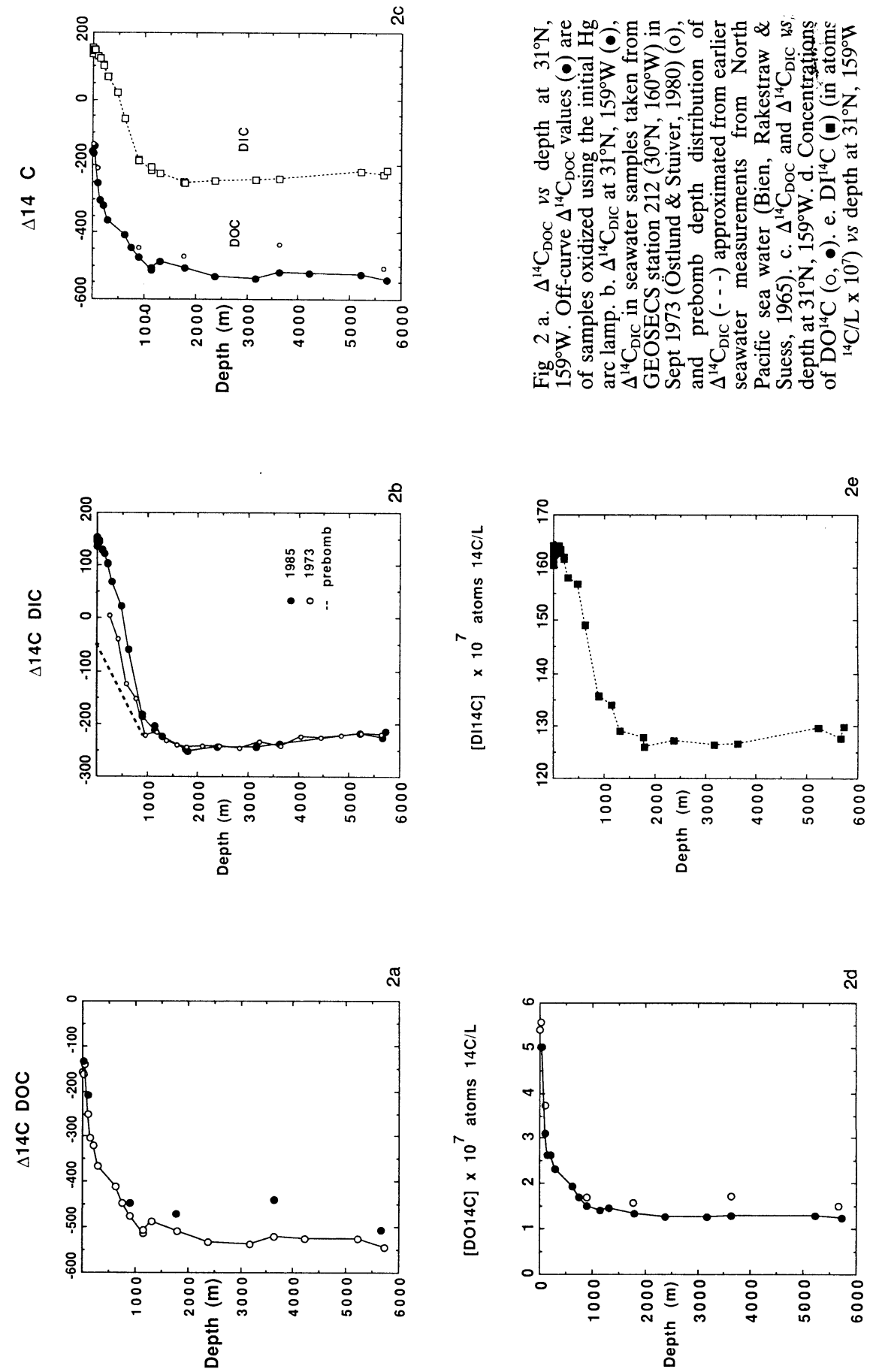
suggests that bomb ${ }^{14} \mathrm{C}$ has penetrated into the DOC pool to at least the same depth as in the DIC pool, that is ca $1000 \mathrm{~m}$. The shift toward lower numbers indicates that a major component of the DOC pool is 'old' with respect to ${ }^{14} \mathrm{C}$, and is recycled on very long time scales $\left(10^{3}-10^{4} \mathrm{yr}\right.$ or longer).

In order to observe changes in the concentration of ${ }^{14} \mathrm{C}$ in each of these carbon pools, $\left[\mathrm{DO}^{14} \mathrm{C}\right]$ and $\left[\mathrm{DI}^{14} \mathrm{C}\right]$ values are calculated using the following equations:

$$
\begin{aligned}
{\left[\mathrm{DO}^{14} \mathrm{C}\right] } & =\left[\delta^{14} \mathrm{C} / 1000+1\right] * \mathrm{f} *[\mathrm{DOC}] * \mathrm{~A} \\
{\left[\mathrm{DI}^{14} \mathrm{C}\right] } & =\left[\delta^{14} \mathrm{C} / 1000+1\right] * \mathrm{f} *[\mathrm{DIC}] * \mathrm{~A}
\end{aligned}
$$

where $\delta{ }^{14} \mathrm{C}$ is defined by Stuiver and Polach (1977), $\mathrm{f}$ is the ${ }^{14} \mathrm{C} / \mathrm{C}$ ratio in $95 \%$ NBS oxalic acid-1 standard $\left(1.176 \times 10^{-12}\right.$; Stuiver, 1980$), \mathrm{A}$ is Avogadro's number, and [DOC] and [DIC] are in moles/L. Figure $2 \mathrm{~d}$ shows that the surface $\left[\mathrm{DO}^{14} \mathrm{C}\right]$ is four times greater than that in the deepsea, whereas surface [DI ${ }^{14} \mathrm{C}$ ] is only 1.3 times that in the deep-sea. The large $\mathrm{DO}^{14} \mathrm{C}$ concentration gradient illustrates that large amounts of DOC are recycled within the upper few hundred meters of the water column by (1) remineralization of organic matter fixed in the euphotic zone, and (2) remineralization of organic matter in the upper $1000 \mathrm{~m}$ of the water column due to microbial and other degradative processes.

Results of vertical profiles of FAA, THAA, TCHO and DOC are listed in Table 1 and shown in Fig 3. The FAA results (Fig 3a) are very low below $450 \mathrm{~m}$ depth; they indicate that there is little if any contamination by labile carbon of the Gerard barrel samples during collection. The low results also illustrate rapid bacterial utilization of FAA in deep waters. The THAA results (Fig 3b) were ca 100 times higher than FAA and show variations with depth. The increase in THAA from $400-800 \mathrm{~m}$ may be caused by partial conversion of the surface-derived particulate organic carbon rain to DOC or insitu production of organic matter (Cindy Lee, pers commun, 1988). The TCHO values are about seven times higher than the THAA values, and are essentially invariant with depth below $900 \mathrm{~m}$. The sum of THAA and TCHO carbon is ca $11 \%$ of the total DOC below $1000 \mathrm{~m}$ and comprises $19 \%$ of the DOC at the surface (Fig 3c).

The seven DOC values denoted by open circles in Figure $3 \mathrm{c}$ are $6-14 \%$ higher than the other DOC values. Likewise, the $\Delta{ }^{14} \mathrm{C}_{\mathrm{DOC}}$ of 6 of these 7 samples were higher than the other values (Fig 2a). We suspect that the higher DOC values were the result of a 'younger' fraction of DOC that was oxidized only in the first seven samples processed using the initial "more potent" Hg-arc UV lamp (for discussion, see Druffel, Williams \& Suzuki, 1989).

${ }^{14} \mathrm{C}$ measured in 11 surface water samples collected over the course of the 33-day cruise are listed in Table 1 . Pre-storm $\Delta{ }^{14} \mathrm{C}_{\text {DIC }}$ results are relatively constant, with an average of $151.3 \pm 0.8(\mathrm{SD}) \%$ o $(n=3)$ through day- 8 of the cruise. Post-storm results, however, were more variable and averaged $146.6 \pm 6.2(\mathrm{SD}) \%(\mathrm{n}=8)$. In order to observe changes in $\mathrm{DI}^{14} \mathrm{C}$ concentration with time $\left[\mathrm{DI}^{14} \mathrm{C}\right]$ values in the surface seawater samples are calculated using Eq 2 and shown in Figure $4 \mathrm{a} .\left[\mathrm{DI}^{14} \mathrm{C}\right]$ was also more variable during the post-storm period. An increase was observed in $\left[\mathrm{DI}^{14} \mathrm{C}\right]$ in the 


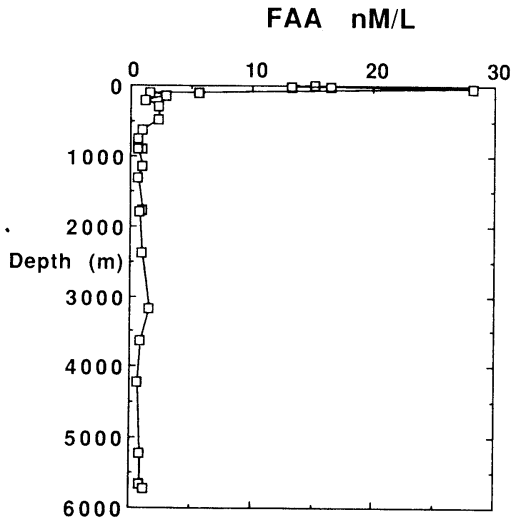

3 a

[THAA+TCHO] and [DOC] $\mu \mathrm{M}$

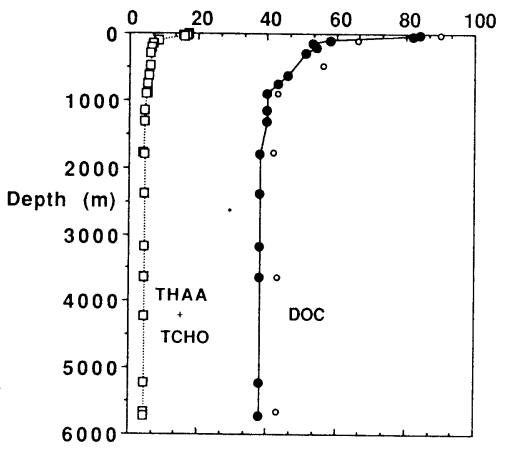

$3 c$

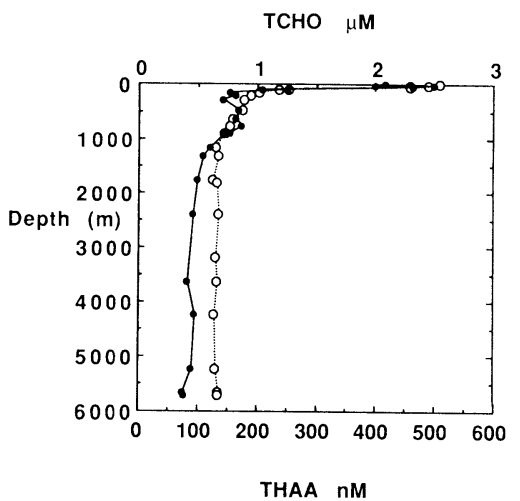

$3 b$

Fig 3. a. Free amino-acid (FAA) concentrations $v s$ depth from $31^{\circ} \mathrm{N}, 159^{\circ} \mathrm{W}$. b. Total dissolved combined (hydrolyzable) amino-acid concentrations (THAA) (•) and total dissolved carbohydrate concentrations (o) $v s$ depth at $31^{\circ} \mathrm{N}, 159^{\circ} \mathrm{W}$. c. UV-oxidizable DOC $(0, \bullet)$ and THAA + TCHO concentrations (as $\mu \mathrm{M}$ in carbon equivalents, (ם) vs depth at $31^{\circ} \mathrm{N}, 159^{\circ} \mathrm{W}$

upper $200 \mathrm{~m}$ during the post-storm period (see Fig $4 \mathrm{~b}$ ), due primarily to the higher total $\mathrm{CO}_{2}$ values. Whether the higher values were due to entrainment of atmospheric $\mathrm{CO}_{2}$ into the mixed layer, or to spatial variability induced by storm activity, cannot be determined from the existing data set.

\section{CONCLUSIONS}

The study of ${ }^{14} \mathrm{C}$ in DOC in the central North Pacific has revealed that a major portion of the DOC is recycled within the water column on time scales of $10^{3}$ to $10^{4} \mathrm{yr}$ or longer. Bomb ${ }^{14} \mathrm{C}$ is present to a depth of at least $1000 \mathrm{~m}$ in the DOC pool, and is probably present in small amounts in the deep sea. Labile constituents of DOC (THAA and TCHO) are present in minor amounts in sea water $(11-19 \%$ of DOC).

The ${ }^{14} \mathrm{C}_{\mathrm{DIC}}$ profile reveals that the bomb ${ }^{14} \mathrm{C}$ transient has penetrated an additional $150-200 \mathrm{~m}$ since the GEOSECS survey of 1973 . These data have important implications for determining the ventilation rate of the main thermocline with respect to excess $\mathrm{CO}_{2}$. 


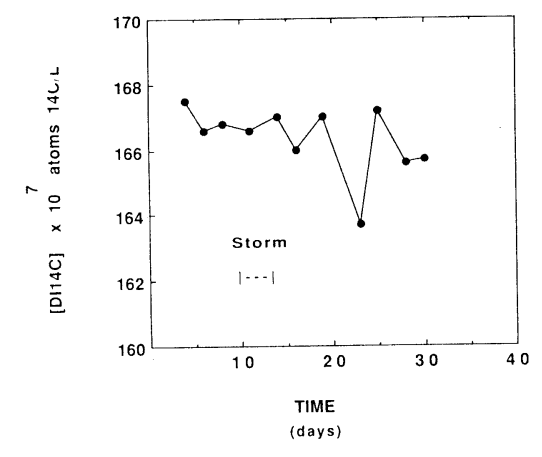

Fig 4 a. $\left[\mathrm{DI}^{14} \mathrm{C}\right]$ in surface sea water $v s$ time during the Alcyone- 5 cruise at $31^{\circ} \mathrm{N}$, $159^{\circ} \mathrm{W}$.

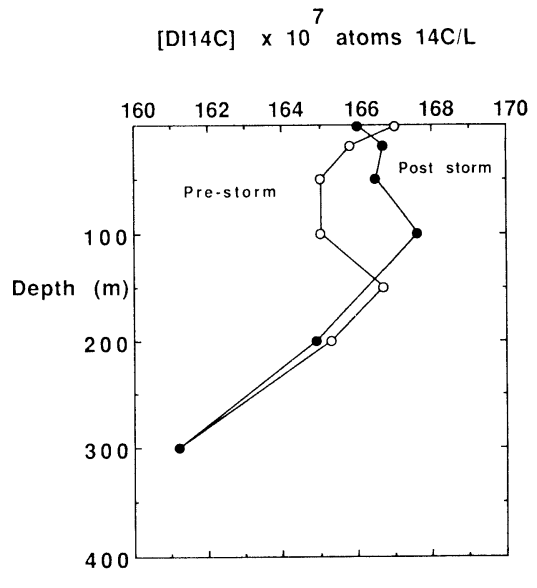

Fig 4 b. $\left[\mathrm{DI}^{14} \mathrm{C}\right]$ vs depth for the preFig 4 b. $\left[\mathrm{DI}^{14} \mathrm{C}\right] v s$ depth for the pre-
storm and post-storm sampling periods.

\section{ACKNOWLEDGMENTS}

We thank the captain and crew of the $R / V$ Melville for their cooperation and support during the Alcyone-5 cruise. Special thanks go to Bob Haddock, Amy Witter and Al Bradshaw for their technical support. This project was kindly supported by funds from the NSF (OCE84-16632 to ERMD and OCE84-17102 to PMW). Woods Hole Oceanographic Institution contribution No. 6993 ?

\section{REFERENCES}

Arhelger, M E, Kinney, P J, Linick, T W and Williams, P M, 1974, The radiocarbon activity of the dissolved and particulate organic carbon in the northeastern Pacific Ocean, in Research on the marine food chain: US Atomic Energy Prog UCSD, p 363-389.

Bada, J and Lee, C, 1977, Decomposition and alteration of organic compounds dissolved in seawater: Marine Chem, v 5, p 523-534.

Bien, G S, Rakestraw, N W and Suess, H E, 1965, Radiocarbon in the Pacific and Indian Oceans and its relation to deep-water movements: Limnol Oceanog, v 10, p R25-R27.

Burney, C M and Sieburth, J McN, 1977, Dissolved carbohydrates in sea water, part 2. A spectrophotometric procedure for total carbohydrate analysis and poly saccharide estimation: Marine Chem, v 5, p 15-28.

Druffel, E R M, Williams, P and Suzuki, Y, 1989, Radiocarbon levels and concentrations of dissolved organic matter in Pacific Ocean waters: Geophys Research Letters, in press.

Griffin, S and Druffel, E R M, 1985, Woods Hole Oceanographic Institution radiocarbon laboratory: Sample treatment and gas preparation: Radiocarbon, v 27, no. 1, p 43-51.

Jull, A J T, Donahue, D J, Hatheway, A L, Linick, T W and Toolin, L J, 1986, Production of graphite targets by deposition from $\mathrm{CO} / \mathrm{H}_{2}$ for precision accelerator ${ }^{14} \mathrm{C}$ measurements, in Stuiver, $M$ and Kra, R S, eds, Internatl ${ }^{14} \mathrm{C}$ conf, 12 th, Proc: Radiocarbon, $v 28$, no. $2 \mathrm{~A}$, p 191-197.

Lindroth, P and Mopper, K, 1979, High performance liquid chromatographic determination of subpicomole amounts of amino-acids by pre column fluorescence derivatization with $o$ phthaldialdehyde: Analytical Chem, v 51, p 1667-1674. 
Linick, T W, (ms) 1975, Uptake of bomb-produced radiocarbon in the surface water of the Pacific Ocean: PhD dissert, Univ California, San Diego, 255 p.

Linick, T W, Jull, A J T, Toolin, L J and Donahue, D J, 1986, Operation of the NSF-Arizona accelerator facility for radioisotope analysis and results from selected collaborative research projects, in Stuiver, $\mathrm{M}$ and $\mathrm{Kra}, \mathrm{R} \mathrm{S}$, eds, Internatl ${ }^{14} \mathrm{C}$ conf, 12th, Proc: Radiocarbon, v 28, no. 2A, p 522-533.

Meyers-Schulte, K J and Hedges, J I, 1986, Molecular evidence for a terrestrial component of organic matter dissolved in ocean water: Nature, v 321, p 61-63.

Östlund, H G and Stuiver, M, 1980, GEOSECS Pacific radiocarbon: Radiocarbon, v 22, no. $1, \mathrm{p} 25-53$.

Robertson, K J, Williams, P M and Bada, J L, 1987, Acid hydrolysis of dissolved combined amino acids in seawater a precautionary note: Limnol Oceanog, v 32, p 996-997.

Stuiver, M, 1980, ${ }^{14} \mathrm{C}$ distribution in the Atlantic Ocean: Jour Gephys Research, v 85, no. C5, p 2711-2718.

Stuiver, M and Polach, H A, 1977, Discussion: Reporting of ${ }^{14} \mathrm{C}$ data: Radiocarbon, v 19, no. $3, \mathrm{p} 355-363$.

Sugimura, Y and Suzuki, Y, 1988, A high temperature catalytic oxidation method of non-volatile dissolved organic carbon in sea water by direct injection of liquid sample: Marine Chem, v 24, p 105-1231.

Williams, P M and Druffel, E R M, 1987, Radiocarbon in dissolved organic matter in the central North Pacific Ocean: Nature, v 330, p 246-248.

Williams, P M and Gordon, L I, 1970, Carbon-13: carbon-12 ratios in dissolved and particulate organic matter in the sea: Deep-Sea Research, v 17, p 19-27.

Williams, P M, Oeschger, H and Kinney, P, 1969, Natural radiocarbon activity of the dissolved organic carbon in the Northeast Pacific Ocean: Nature, v 224, p 256-258.

Williams, P M, Stenhouse, M C, Druffel, E M and Koide, M, 1978, Organic carbon-14 activity in an abyssal marine sediment: Nature: $v$ 276, p 698-701. 